\title{
Detection and enumeration of the dangerous food borne pathogens in cooked food that causes food poisoning and infectious diseases
}

\author{
Sumonthip KongtunJanphuk ${ }^{1 *}$ \\ ${ }^{1}$ Department of Biotechnology, King Mongkut's University of Technology North Bangkok, Bangkok, Thailand
}

\begin{abstract}
This research was aim to analyzed the detection and enumeration of the dangerous food borne pathogens in cooked food that causes food poisoning and infectious diseases from the restaurants surround area of King Mongkut's University of Technology North Bangkok, Bangkok, THAILAND. Pot-stewed pork (Palow-Moo;PL) and Fried basil pork (Kapraw-Moo;PK) from five restaurants were collected and analyzed for food borne pathogens. The Analysis of bacterial contamination in that food by used to the methodology of Microbiology and diagnosis bacteria by Biochemistry methodology. The result were indicated that the cooked food from five restaurants contaminated with bacteria caused the risk of gastrointestinal disease as follows : PL dishes the microorganisms were founded between $1 \times 10^{5}$ to $3 \times 10^{8}$ colony/gram, MPN values in the ranges of Escherichia coli were infected $<3$ to 64 and MPN values of Staphylococcus aureus $<3$ to 43. There were founded Salmonella spp. 5 samples, Pseudomonas aeruginosa 4 samples, Shigella spp. 4 samples, Bacillus cereus 2 samples, Proteus spp. 2 sample and Micrococcus spp. 1 sample. In the PK dished, the total number of bacteria were founded between $5 \times 10^{3}$ to $2 \times 10^{8}$ colony/gram, MPN values in the range of E.coli and S.aureus were infected $<3$ to 39 and $<3$ to 28 . The results showed that the cooked food from five restaurants are contaminated with bacterial caused food poisoning and the risk of gastrointestinal diarrhea at the different levels.
\end{abstract}

\section{Introduction}

Food borne pathogens such as Escherichia coli, Staphylococcus aureus, Pseudomonas aeruginosa, Salmonella spp., Shigella spp., Bacillus cereus, Proteus spp., or Micrococcus spp. have been recognized for more than 100 years. Those pathogens can transmit through food and cause the food borne diseases which some of diseases are considered as a serious problem for public health. Symptoms of food borne diseases caused by pathogens depending on the type of infectious pathogen and the amount of food intake, which often include vomiting, fever, and diarrhea. Some pathogens can pass through the stomach into intestine and multiply, extended the food borne disease, and some can produce a toxin that can pass into the bloodstream, caused the more serious problems in the deeper body issues [1-3].

There are more than 30 restaurants around King Mongkut's University of Technology North Bangkok (KMUTNB) serving students, teachers, staff and people who live around this area. The pre-cooked food (readyto-eat) restaurant is one of the most popular type because of the cheap price, large quantity, and various choices of foods. Two kinds of food that usually found in those restaurants are Pot-stewed pork (Palow-Moo;PL) and Fried basil pork (Kapraw-Moo;PK). In this study, PL and PK from 4 restaurants around KMUTNB and in the canteen of the university were collected and tested for food borne pathogens. The risky score of both type of food in all restaurants were evaluated according to the type of pathogens found in samples.

\section{Materials and Methods}

\subsection{Sample preparation}

Pot-stewed pork (Palow-Moo;PL) and Fried basil pork (Kapraw-Moo;PK) from four restaurants (South(S), $\operatorname{North}(\mathrm{N})$, West(W), East(E)) within the $1 \mathrm{~km}$ radius around the university and one restaurant in the campus(C) were collected 1 sample/week for 10 weeks consecutively. Pot-stewed pork samples were labeled as PLS, PLN, PLW, PLE and PLC, and Fried basil pork samples were labeled as PKS, PKN, PKW, PKE and PKC. Samples were kept in the plastic boxes with lids and immediately tested in the laboratory.

Samples were crushed by the food blender, and then squeezed until the juice was obtained. The $\mathrm{pH}$ and ${ }^{\circ}$ Brix values of the samples were checked before the microbiological analysis.

\footnotetext{
* Corresponding author: skongtun@yahoo.com
} 


\subsection{Microbiological analysis [4-6]}

All food samples were diluted using serial dilution technique. The isolation of the bacteria was performed using spread plate and streaking plate methods. The isolated bacteria were specified using Biochemical methods that described below;

\subsubsection{Gram Stain Technique}

The smear was prepared on a clean grease/oil-free slide. It allowed to air dry and then held the slide at one end and passed the entire slide through the flame of a Bunsen burner for a few times with the smear-side up. The crystal violet was gently drop over the smear and left to stain for $1 \mathrm{~min}$. It was gently rinsed with distilled water and then flooded the smear with Gram's iodine, let it stand for $1 \mathrm{~min}$. It was eluted using $95 \%$ ethyl alcohol until the eluted solution runs almost clear, and then immediately rinsed with water. The smear was continuously stain with safraninO for $1 \mathrm{~min}$, then rinsed with distilled water, blot dry the slide with tissue paper before observed the smear under the microscope (100x).

\subsubsection{Catalase test}

Bacteria were grown on a Nutrient Broth and incubated at temperature of $37{ }^{\circ} \mathrm{C}$ for $18-24 \mathrm{hr}$. A few drops of $\mathrm{H}_{2} \mathrm{O}_{2}$ were applied onto a clean slide, followed by bacteria suspension. Gas wasusually evolved immediately.

\subsubsection{Oxidase test}

A filter paper which was saturated with $0.5 \%$ tetramethyl-p-phenylenediamine $\mathrm{HCI}$ was used then placed a small amount of bacteria to the paper. The positive reaction (bacteria change color to purple) would be observed immediately or within 10 seconds.

\subsubsection{Methyl Red (MR) test}

Bacteria were grown on a MR-VP liquid medium and incubated at temperature of $37{ }^{\circ} \mathrm{C}$ for $48 \mathrm{hr} .5 \mathrm{ml}$ of Suspension was added into test tube, after that 5-6 drops of Methyl red were applied. The positive reaction was red color and negative color was yellow. If orange color at the top of the test sample was observed, let it stand for $48 \mathrm{hr}$ and observed the result again.

\subsubsection{Voges-Proskauer (VP) test}

Bacteria were grown on a MR-VP liquid medium and incubated at temperature of $37{ }^{\circ} \mathrm{C}$ for $48 \mathrm{hr} .1 \mathrm{ml}$ of Suspension was added into test tube, then added $0.5 \mathrm{ml}$ of $5 \%$ naphthol solution and $0.2 \mathrm{ml}$ of $40 \%$ potassium hydroxide. The test sample was shaken until it mixed well and observed within $5 \mathrm{~min}$. The positive reaction was red color and negative color was yellow.

\subsubsection{Indole test}

Bacteria were grown on a Tryptone liquid medium and incubated at temperature of $37^{\circ} \mathrm{C}$ for $24-48 \mathrm{hr} .1 \mathrm{ml}$ of Suspension was added into test tube, then $5 \mathrm{ml}$ of Kovacs' reagent was added. The positive reaction was red color on the top layer and negative color was no color.

\subsubsection{Citrate utilization test}

Bacteria were placed on Simmons' Citrate agar using a sterile loop and incubated at temperature of $37^{\circ} \mathrm{C}$ for 24$48 \mathrm{hr}$ (maximum 7 days). The positive reaction would turn the medium color from green to blue.

\subsubsection{Gelatin liquefaction test}

Bacteria were placed on the bottom of nutrient gelatin medium using a sterile needle and incubated at temperature of $37^{\circ} \mathrm{C}$ for $48 \mathrm{hr}$. The control sample (no bacteria added) was prepared with the same procedure. After $48 \mathrm{hr}$, samples and control were placed into refrigerator for $2 \mathrm{hr}$, and then turbidity of samples was observed compared with the control.

\subsubsection{Nitrate reduction test}

Bacteria were grown on a trypticase-nitrate broth and incubated at temperature of $37^{\circ} \mathrm{C}$ for $48 \mathrm{hr} .1 \mathrm{ml}$ of 0.8 sulfanilic acid solution and $1 \mathrm{ml}$ of $0.6 \%$ dimethyl- $\alpha-$ naphthylamine solution were added. Positive nitrite reduction would be red color. In the case of no color, zinc dust was added into the sample, the red color appeared in the Negative Nitrate Reduction.

\subsubsection{Urease test}

Bacteria were placed on the top of Christensen's urea agar slant using a sterile needle and incubated at temperature of $37^{\circ} \mathrm{C}$ for $6-24 \mathrm{hr}$. The positive reaction would turn the medium color to pinkish-red.

\subsubsection{Malonate test}

Bacteria were placed on the top malonate broth and incubated at temperature of $37^{\circ} \mathrm{C}$ for $24-48 \mathrm{hr}$. The positive reaction would turn the medium color to blue and the negative reaction was yellow, brown or no change.

\subsubsection{Motility test}

Bacteria were placed on the middle of motility test medium (semi-solid) with a depth of $1 / 2$ inch using a sterile needle and incubated at temperature of $37{ }^{\circ} \mathrm{C}$ for $24-48 \mathrm{hr}$. The positive result would showed the turbidity spread around the growth area. 


\subsubsection{Triple Sugar Iron (TSI) agar test}

Bacteria were inoculated into TSI using a sterile needle by stabbing through the center of the medium to the bottom of the tube and then streak the surface of the slant. The incubation was operated at temperature of 37 ${ }^{\circ} \mathrm{C}$ for 18-24 hr. The samples were observed for color change in the slant and the bottom and gas in the medium.

\subsubsection{Carbohydrate Fermentation test}

The bacteria were inoculated into Andrade's carbohydrate broth medium of lactose, sucrose, fructose, galactose, xylose, rhamnose, raffinose, trhalose, cellobiose, inulin, salicin, adonital, sorbitol and mannitol. The incubation was operated at temperature of $37^{\circ} \mathrm{C}$ for $18-24 \mathrm{hr}$. The samples were observed for color change and gas in the Durham tube.

\section{Results}

The $\mathrm{pH}$ and Brix value of all 10 samples were shown in Table 1 . There are 8 food borne pathogens which were Bacillus cereus, Shigella spp., Staphylococcus aureus, Micrococcus spp., Salmonella spp., Proteus spp.,
Escherichia coli, Pseudomonas spp., found in precooked samples in this study compared with Bergey's manual of determinative bacteriology (Bergy's 1994) (Table 2). The microorganism contamination results of 10 samples were shown in Table 3, compared with the guidance for food safety in ready-to-eat food criteria (Department of Medical Science (DMSC), Ministry of Public Health, Thailand).

Table 1. $\mathrm{pH}$ and ${ }^{\circ}$ Brix values of 10 pre-cooked samples.

\begin{tabular}{|l|l|l|}
\hline Sample & $\mathrm{pH}$ & ${ }^{\circ}$ Brix \\
\hline PLS & 5.24 & 18.1 \\
\hline PLN & 6.58 & 15.6 \\
\hline PLW & 6.94 & 16.9 \\
\hline PLE & 6.21 & 16.3 \\
\hline PLC & 5.79 & 17.5 \\
\hline PKS & 5.90 & 32.0 \\
\hline PKN & 6.03 & 24.3 \\
\hline PKW & 6.73 & 19.7 \\
\hline PKE & 5.43 & 22.9 \\
\hline PKC & 6.61 & 26.1 \\
\hline
\end{tabular}

$\mathrm{PL}=$ Pot-stewed pork, $\mathrm{PK}=$ Fried basil pork

Table 2. Food borne pathogenic bacteria found in pre-cooked samples.

\begin{tabular}{|c|c|c|c|c|c|c|c|c|c|c|}
\hline \multirow{2}{*}{ Food borne pathogens } & \multicolumn{10}{|c|}{ Pre-cooked samples } \\
\hline & PLS & PLN & PLW & PLE & PLC & PKS & PKN & PKW & PKE & PKC \\
\hline Bacillus cereus & & + & & + & & & + & & + & \\
\hline Shigella $\mathrm{spp}$ & + & & + & + & + & + & + & + & & + \\
\hline Staphylococcus aureus & + & + & + & + & + & & + & + & + & + \\
\hline Micrococcus spp. & & & + & & & + & & + & + & \\
\hline Salmonella spp. & + & + & + & + & + & & + & + & + & + \\
\hline Proteus spp. & & + & & + & & + & + & & + & \\
\hline Escherichia coli & + & + & + & & + & + & + & + & + & + \\
\hline Pseudomonas spp. & + & & + & + & + & & & + & + & + \\
\hline
\end{tabular}

+ : Positive (found in samples)

Table 3. Evaluation of pre-cooked food sample (based on criteria of cooked food standard from Department of Medical Science, Ministry of Public Health, Thailand)

\begin{tabular}{|c|c|c|c|c|c|c|c|c|c|c|c|}
\hline \multirow[t]{2}{*}{ Criteria } & \multicolumn{10}{|c|}{ Pre-cooked food samples } & \multirow{2}{*}{$\begin{array}{l}\text { DMSC } \\
\text { guidance* }\end{array}$} \\
\hline & PLS & PLN & PLW & PLE & PLC & PKS & PKN & PKW & PKE & $\mathrm{PKC}$ & \\
\hline Total Viable count & $>1 \times 10^{6}$ & $>1 \times 10^{6}$ & $>1 \times 10^{6}$ & $>1 \times 10^{6}$ & $>1 \times 10^{6}$ & $>1 \times 10^{6}$ & $>1 \times 10^{6}$ & $>1 \times 10^{6}$ & $>1 \times 10^{6}$ & $>1 \times 10^{6}$ & $<1 \times 10^{6}$ \\
\hline MPN E. coli/gram & $>3$ & $>3$ & $>3$ & NF & $<3$ & $<3$ & $>3$ & $>3$ & $>3$ & $<3$ & $<3$ \\
\hline S. aureus & $<100$ & $<100$ & $<100$ & $<100$ & $<100$ & NF & $<100$ & $<100$ & $<100$ & $<100$ & $<100$ \\
\hline C. perfringens & NF & $\mathrm{NF}$ & NF & $\mathrm{NF}$ & NF & $\mathrm{NF}$ & NF & NF & NF & NF & $<100$ \\
\hline B. cereus & $\mathrm{NF}$ & $<100$ & NF & $>100$ & NF & $\mathrm{NF}$ & $<100$ & NF & $>100$ & $\mathrm{NF}$ & $<100$ \\
\hline Salmonella spp. & + & + & + & + & + & $\mathrm{NF}$ & + & + & + & + & $\mathrm{NF}$ \\
\hline V. cholerae & NF & NF & $\mathrm{NF}$ & NF & $\mathrm{NF}$ & $\mathrm{NF}$ & NF & NF & $\mathrm{NF}$ & $\mathrm{NF}$ & NF \\
\hline V. parahaemolyticus & NF & NF & NF & NF & NF & NF & NF & NF & NF & NF & NF \\
\hline L. monocytogenes & $\mathrm{NF}$ & $\mathrm{NF}$ & NF & NF & NF & $\mathrm{NF}$ & NF & NF & $\mathrm{NF}$ & $\mathrm{NF}$ & $\mathrm{NF}$ \\
\hline
\end{tabular}

* based on DMSC food safety criteria guidance for pre-cooked food (Ready-to-eat) 11 January 2016. 


\section{Discussion and Conclusion}

All pre-cooked foods from 5 restaurants were contaminated with the food borne pathogenic bacteria in the different levels and all of those samples did not passed the total viable count criteria of DMSC food safety guidance for pre-cooked food. According to Table 3 , the test results PL and PK samples from the same restaurant were similar, which assumed as the contaminate of pathogens from the cooking process of each place.

\section{Acknowledgement}

This work was supported by grants from the King Mongkut's University of Technology North Bangkok Fund KMUTNB-GEN -59-44 and Faculty of Applied Science, King Mongkut's University of Technology North Bangkok. The author cordially thanks Department of Medical Science (DMSC), Ministry of Public Health, Thailand and Thai traditional medicine development center, Ministry of Public Health, Thailand, for the instrument support. Finally I would like to thank Ms. Chompoonuch Rassamee, Ms. Patcharin Jittisak and Dr. Jutamas Sangsaiwho helped to complete the research.

\section{References}

1. R.G. Labbe, S. Garcia, editors, Guide to Foodborne Pathogens (John Wiley and Sons, Inc, New York, 2001)

2. M.D. Miliotis, J.W. Bier, editors, International Handbook of Foodborne Pathogens (Marcel Dekker, Inc., New York, 2003)

3. P.M. Fratamico, A.K. Bhunia, J.L. Smith, editors, Food borne Pathogens Microbiology and Molecular Biology (Caister Academic Press, Norfolk, 2005)

4. P.H. Clarke, S.T. Cowan, J. Gen. Micro. biol. 6, 187-197 (1952)

5. B. Priyanka, R.K. Patil, S. Dwarakanath, Indian J. Med. Res. 144, 327-338 (2016)

6. D.H.Bergy, J.G Holt,editors, Bergey's manual of determinative bacteriology (Baltimore : Williams \& Wilkins, 1994) 